\title{
Moderate intake of sucrose does not impair metabolic control in pump-treated diabetic out-patients
}

\author{
E. A. Chantelau, G. Gösseringer, G. E. Sonnenberg and M. Berger \\ Department of Medicine, Düsseldorf University, Düsseldorf, FRG
}

Summary. The effects of dietary intake of sucrose versus the use of sodium cyclamate were studied in 10 Type 1 (insulindependent) diabetic patients on continuous subcutaneous insulin infusion therapy. After a 4-week run-in period, the patients were randomly assigned to a cross-over protocol with two 4-week periods during which they used sucrose or sodium-cyclamate as sweetener. During the experimental periods, $24 \pm 13 \mathrm{~g} /$ day sucrose and $348 \pm 270 \mathrm{mg} /$ day of sodium cyclamate were consumed, respectively. Metabolic control was monitored by the patients performing blood glucose selfmonitoring several times daily. Bi-weekly, all patients were followed-up in our outpatient clinic. Mean daily blood glu- cose concentrations as well as the average daily insulin dose did not differ between the three experimental periods. $\mathrm{HbA}_{\mathrm{Ic}^{-}}$ levels, serum lipids and body weight remained unchanged and within the normal ranges throughout the study. Thus, moderate dietary intake of sucrose did not affect metabolic control in these normal weight, near-normoglycaemic, normolipidaemic, pump-treated Type 1 diabetic patients during a 1-month period. Whether similar conclusions apply to less well controlled diabetic patients remains to be seen.

Key words: Type 1 diabetes, sucrose, diet, metabolic control.
Recently, Bantle et al. [1] and Slama et al. [2] have shown that sucrose taken during a mixed meal has no additional hyperglycaemic effect over an isocaloric amount of starch in patients with diabetes mellitus. Their studies were conducted under experimental conditions, using defined testmeals and an artificial pancreas for intravenous insulin delivery [2]. However, the potential effects of a long-term use of sucrose in Type 1 diabetes are unknown. Therefore, we have studied the metabolic effects of sucrose included in the diet of Type 1 diabetic outpatients treated with continuous subcutaneous insulin infusion.

\section{Subjects and methods}

\section{Patients}

Ten Type 1 diabetic subjects, eight women and two men, aged 25-43 years with a diabetes duration of 6-18 years, volunteered to participate in the study which was carried out in accordance with the Helsinki Declaration [3]. All were C-peptide negative (postabsorptive C-peptide levels $<0.2 \mathrm{ng} / \mathrm{ml}$ ) and of normal body weight (body mass index $<25 \mathrm{~kg} / \mathrm{m}^{2}$ ). The patients had been on continuous subcutaneous insulin infusion therapy $[4,5]$ and a "liberalized diet" [6] for more than 1 year. Their daily insulin dose was $0.56 \pm 0.10 \mathrm{U} / \mathrm{kg}$ body weight (mean $\pm \mathrm{SD}$ ). At the beginning of the study, they were well controlled, as indicated by near-normal $\mathrm{HbA}_{\mathrm{Ic}}-\mathrm{lev}-$ els and normal serum lipids (Table 1).

\section{Study protocol}

After a 4-week run-in period, patients were assigned to use either sucrose or sodium-cyclamate as sweetener in random order for 4 weeks each. They were then asked to change over to sodium-cyclamate or sucrose, respectively, for another 4-week period. During the sucroseperiod, sucrose and sucrose-sweetened foods were allowed ad libitum. The patients were provided with a brochure listing the carbohydrate and sugar content of sucrose-containing foods. The intake of sucrose-sweetened soft drinks, however, was discouraged.

During the cyclamate period, sodium cyclamate was allowed ad libitum within the limitations set up by the World Health Organisation [7], i.e. not more than $11 \mathrm{mg} / \mathrm{kg}$ body weight per day. 
Table 1. Metabolic control in 10 patients on continuous subcutaneous insulin infusion during the three study periods

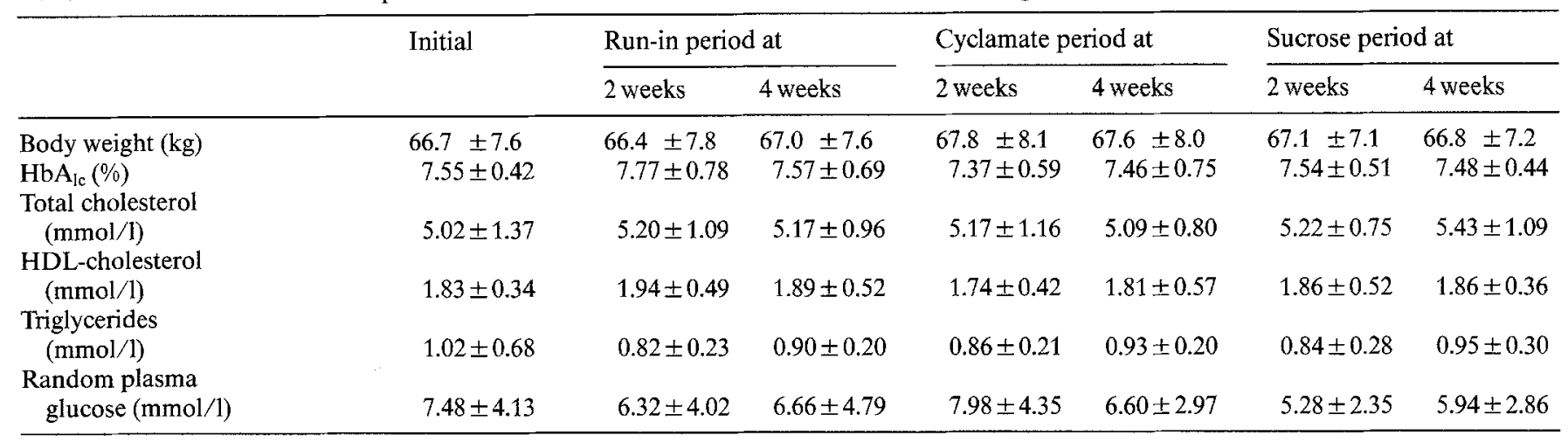

Table 2. Evaluation of metabolic self-control (daily blood glucose readings) and food intake (recorded in detail on 3 consecutive days during each study period) as recorded by the 10 patients studied

\begin{tabular}{|c|c|c|c|}
\hline & $\begin{array}{l}\text { Run-in } \\
\text { period }\end{array}$ & $\begin{array}{l}\text { Cyclamate } \\
\text { period }\end{array}$ & $\begin{array}{l}\text { Sucrose } \\
\text { period }\end{array}$ \\
\hline $\begin{array}{l}\text { No. of blood glucose } \\
\text { readings } / 4 \text { weeks (total) }\end{array}$ & 1273 & 1292 & $1420^{*}$ \\
\hline $\begin{array}{l}\text { No. of blood glucose } \\
\text { readings/patient. day }\end{array}$ & $4.2 \pm 0.3$ & $4.3 \pm 0.3$ & $4.7 \pm 0.4^{*}$ \\
\hline $\begin{array}{l}\% \text { of blood glucose } \\
\text { readings }<2.5 \mathrm{mmol} / 1\end{array}$ & 3 & 4 & 4 \\
\hline $\begin{array}{l}\text { Daily intake of } \\
\text { carbohydrates }(\mathrm{g}) \\
\text { fat }(\mathrm{g}) \\
\text { protein }(\mathrm{g})\end{array}$ & $\begin{array}{r}236 \pm 75 \\
103 \pm 42 \\
79 \pm 42\end{array}$ & $\begin{array}{r}191 \pm 79 \\
84 \pm 41 \\
77 \pm 38\end{array}$ & $\begin{array}{r}216 \pm 79 \\
109 \pm 49 \\
90 \pm 44\end{array}$ \\
\hline
\end{tabular}

$\left(^{*}=p<0.05\right.$ versus run-in, or cyclamate period; unpaired comparison)

\section{Self-monitoring of metabolic control and of food intake}

The patients performed regular blood glucose self-monitoring using battery powered reflectance meters or reagent strips only. The quality of blood glucose self-monitoring was repeatedly checked against laboratory techniques. The glucose readings, the daily insulin doses (basal and prandial insulin supply) and the intake of carbohydrates were recorded every day in a diary. For study purposes, patients were asked to note the frequency and the amount of sucrose intake as assessed in common measures, such as "one teaspoon of sugar", "one sugar cube", "one Mars bar", "one piece of Black Forest cake" etc. During the cyclamate period, the patients were given packages of cyclamate tablets and liquids. The consumption of sodium cyclamate was assessed at the end of the study period by counting the tablets and measuring the liquids that were left.

To obtain a more detailed assessment of nutrient intake, a 3-day dietary monitoring period was carried out within each of the three observation periods. Standardized check-lists were used, containing commonly eaten foodsstuffs described in commonly used measures, such as "one half slice of white bread", "one cup of nuts", etc. These foodcharts were to be filled in by the patients during their meals (modified "notes at the table" [8]).

\section{Assessment of metabolic control}

Bi-weekly, all patients were followed up in our outpatient clinic for determination of body weight, random postprandial plasma glucose, $\mathrm{HbA}_{\mathrm{Ic}}$-levels, and nonfasting serum concentrations of total cholesterol, HDLcholesterol and triglycerides. Plasma glucose was measured using a Beckman glucose analyzer (Beckman Instruments, Fullerton, California, USA). $\mathrm{HbA}_{\mathrm{Ic}}$ levels were determined according to Flückinger and Winterhalter [9]; the normal range for $\mathrm{HbA}_{\mathrm{Ic}}$ was $4.1-7.8 \%$. Serum lipids were measured using standard laboratory techniques [10].

\section{Statistical evaluation}

Student's t-test was used for paired and unpaired comparison. The criterion of statistical significance was $(p<0.05$. In the text and tables, data are given as mean $\pm S D$, in the figures as mean $\pm S E M$.

\section{Results}

During the 4-week periods, the patients consumed $717 \pm 377 \mathrm{~g}$ (range $310-1497 \mathrm{~g}$ ) of sucrose, i.e. $24 \pm 13 \mathrm{~g}$ of sucrose per day and $10.46 \pm 8.09 \mathrm{~g}$ (range $2.4-30 \mathrm{~g}$ ) sodium cyclamate, i.e. $348 \pm 270 \mathrm{mg}$ sodium cyclamate per day (approximately $5 \mathrm{mg} / \mathrm{kg}$ body weight per day), respectively. The evaluation of the 3-day dietary monitoring revealed that nutrient intake was comparable between the three observation periods, with regard to the consumption of carbohydrates, protein and fat (Table 2).

The frequency of blood glucose self-monitoring was significantly higher during the sucrose period (Table 2 ). The frequency of blood glucose readings of $<$ $2.5 \mathrm{mmol} / 1$ indicating biochemical hypoglycaemia, was comparable during all three study periods (Table 2). Mean daily blood glucose concentrations ranged between 5.5 and $9.5 \mathrm{mmol} / 1$, except for patient 9 (Fig. 1). The differences between the three observation periods were statistically insignificant. Patient 9 had frequent technical problems with her insulin pump and the 

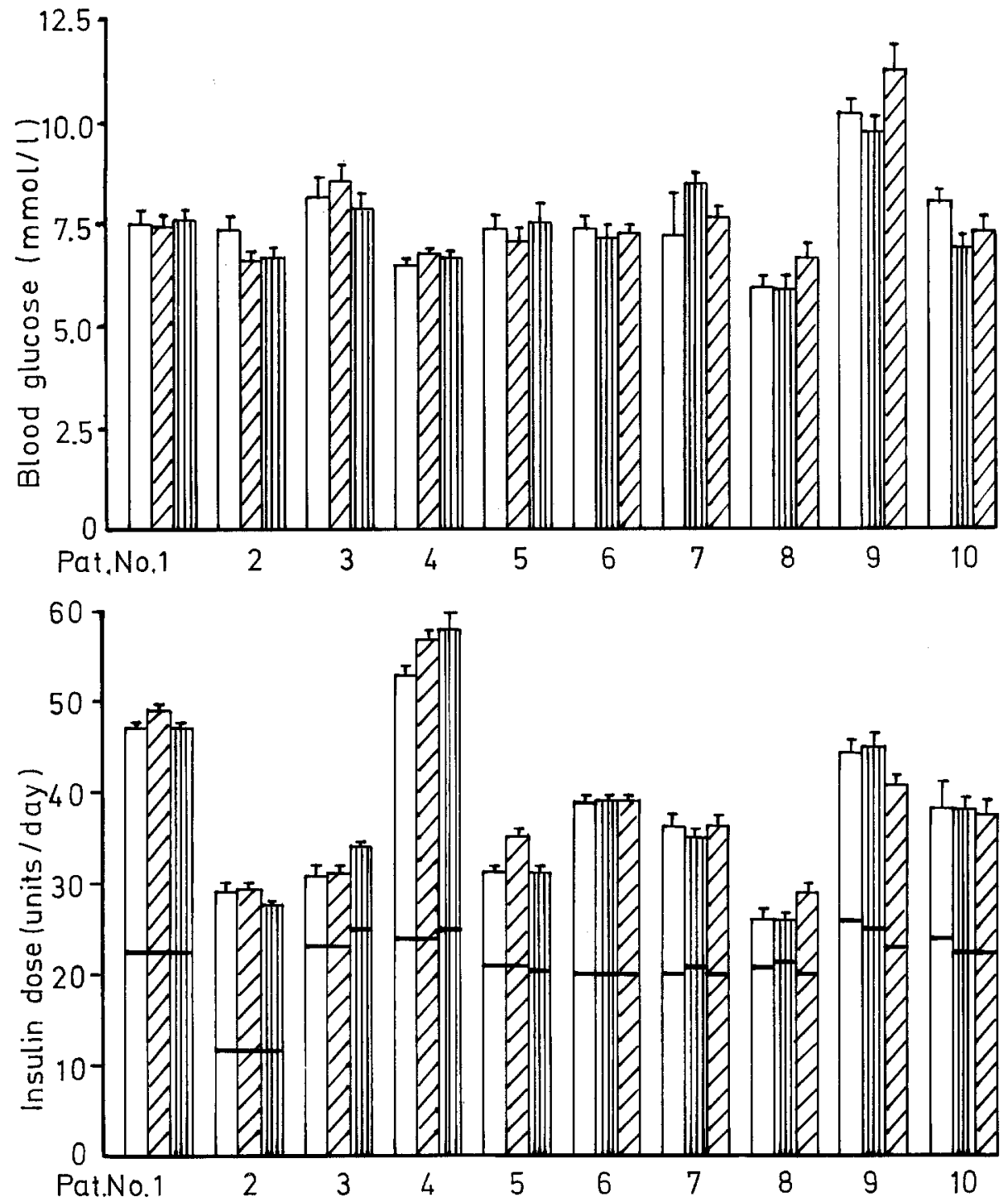

Fig. 1. Mean daily glycaemia based upon blood glucose self-monitoring as performed and recorded by the 10 patients of the study during the three experimental periods of 4 weeks' duration each. $\square$ run-in period;

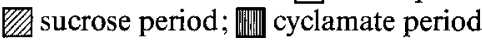

Fig. 2. Mean daily insulin dose delivered subcutaneously by insulin pump as recorded by the 10 patients studied during the three experimental periods of 4 weeks' duration each. Symbols as in Figure 1. The horizontal lines divide the insulin dose delivered as the basal insulin infusion rate (lower part of the bars) from the sum of the pre-prandial insulin boluses given during $24 \mathrm{~h}$ catheter materials. In relation to such difficulties, she recorded episodes of hyperglycaemia; hence, her $\mathrm{HbA}_{\mathrm{Ic}}$ levels were somewhat higher $\left(\mathrm{HbA}_{\mathrm{Ic}} 8.12-8.82 \%\right)$ than those of the other patients. Patients did not change their insulin-meal-timing and the mean daily insulin supply did not differ significantly between the study periods: neither the basal insulin infusion rate nor the prandial insulin requirements changed significantly between study periods (Fig. 2). Body weight and metabolic control measured during the bi-weekly visits of the patients to our outpatient clinic are summarized in Table 1. There were no significant differences between the three observation periods with regard to body weight, $\mathrm{HbA}_{\mathrm{Ic}^{-}}$ levels and serum lipids, all of which remained unchanged within the normal range (except for the $\mathrm{HbA}_{\mathrm{Ic}}$ levels of patient 9 ).

\section{Discussion}

Traditionally, sucrose has been banned from the diet of diabetic patients, although this dogma appears to lack adaequate sicientific support [11]. In fact, sucrose has repeatedly been shown to have comparable glycaemic effects to many other carbohydrates when given during testmeal studies [1,2,12-15]. This study shows that Type 1 diabetic outpatients on continuous subcutaneous insulin infusion therapy did not experience any metabolic disadvantages during a 1-month period when including moderate amounts of sucrose (approximately $10 \%$ of their total carbohydrate intake) in their diet (albeit the study period may have been too short to detect subtle changes in $\mathrm{HbA}_{\text {Ic }}$ levels). An average sucrose consumption of $24 \mathrm{~g} /$ day did not induce weight gain, hyperlipoproteinaemia, or increasing insulin requirements in these subjects; indicating that the patients had exchanged the amount of carbohydrates derived from sucrose isocalorically against carbohydrates from other sources. This is in line with the instructions given to the patients at the initiation of pump treatment [6] according to which the amount of carbohydrate to be ingested is one of the main determinants of the prandial insulin requirement $[16,17]$.

The diet notebooks revealed that the patients ate honey, Danish pastry, pudding, ice-cream, sweets, jam, 
table sugar, or (in moderate quantities) drank soft drinks during the sucrose period. However, they used sucrose as a sweetener and did not abuse it as a nutrient - something which cannot be said of the general population of our Western industrialized societies $[18,19]$.

This study indicates that a moderate consumption of sucrose within the limitations set up by the British National Advisory Committee on Nutrition Education [20] for the general population may have no adverse effect in normal weight, normolipidaemic, near-normoglycaemic Type 1 diabetic patients on insulin-pump therapy.

Although sucrose is not an essential foodstuff, and artificial sweeteners are a reasonable alternative, it appears no longer justified to totally withhold sucrose from the nutrition of well-controlled, non-obese, normolipidaemic Type 1 diabetic patients. However, large amounts of rapidly digested sucrose-containing foods or drinks should be discouraged as their glycaemic effects might arise too intensively to be covered by the action of subcutaneously administered insulin.

In accordance with Slama et al. [2] we hypothesize that liberalization of the diet and in particular of the sucrose intake within such limitations might have positive effects on overall diabetes management in Type 1 diabetes mellitus, as it may help these patients to comply with the more important aspects of diabetes care [21], such as metabolic self-monitoring and insulin dosage adaptation.

\section{References}

1. Bantle JP, Laine DC, Castle GW, Thomas JW, Hoogwerf BJ, Goetz FC (1983) Postprandial glucose and insulin responses to meals containing different carbohydrates in normal and diabetic subjects. N Engl J Med 309: 7-12

2. Slama G, Haardt MJ, Jean-Joseph P, Costagliola D, Giocolea I, Bornet F, Elgrably F, Tchobroutsky G (1984) Sucrose taken during mixed meal has no additional hyperglycaemic action over isocaloric amounts of starch in well controlled diabetics. Lancet 2: 122-4

3. Editorial (1978) The policy of the European Association for the Study of Diabetes on human investigation. Diabetologia 15: $431-2$

4. Sonnenberg GE, Chantelau EA, Berger M (1982) Routine treatment of insulin dependent diabetes mellitus with continuous subcutaneous insulin infusion. In: Skyler JS (ed) Insulin update 1982. Excerpta Medica, Amsterdam Princeton, pp 97-110

5. Chantelau EA, Sonnenberg GE, Best F, Heding LG, Berger M (1984) Target fasting glycaemia for pump-treated type-I diabetics. Klin Wochenschr 62:328-330
6. Chantelau EA, Bockholt M, Lie KT, Broermann C, Sonnenberg GE, Berger M (1983) Diet and pump-treated diabetes: a long-term follow-up. Diabete Metab (Paris) 9:277-282

7. Joint FAO/WHO Expert Committee on Food Additives (1982) Evaluation of certain food additives and contaminants. World Health Organization, Technical Report Series No.683, Geneva, Switzerland

8. Pudel V, Schlaf G, Tischner G, Jansen J (1982) Läßt sich individuelle Ernährungsinformation standardisieren? Ernährungs-Umschau 29:390-395

9. Flückiger R, Winterhalter K (1976) In vitro synthesis of haemoglobin $A_{\text {Ic. }}$. FEBS Lett $71: 356-363$

10. Berchtold P, Berger M, Jörgens V, Daweke C, Chantelau EA, Zimmermann H (1981) Cardiovascular risk factors and HDL-cholesterol levels in obesity. Int $J$ Obes 5:1-10

11. Nuttall FQ (1983) Diet and the diabetic patients. Diabetes Care 6: 197-207

12. Crapo PA, Olefsky JM (1983) Food fallacies and blood sugar. New Engl J Med 309: 44-45

13. Jenkins DJA, Wolever TMS, Taylor RH, Barker $H$, Fielden $H$, Baldwin JM, Bowling AC, Newman HC, Jenkins AL, Goff AV (1981) Glycaemic index of foods: a physiological basis for carbohydrate exchange. Am J Clin Nutr 34: 362-366

14. Jenkins DJA, Wolever TMS, Jenkins AL, Thorne JM, Lee R, Kalmusky J, Reichert R, Wong GS (1983) The glycaemic index of foods tested in diabetic patients: a new basis for carbohydrate exchange favouring the use of legumes. Diabetologia 24: 257-264

15. Schauberger G, Brinck UC, Guldner G, Spaethe R, Niklas L, Otto $H$ (1977) Exchange of carbohydrates according to their effect on blood glucose. Diabetes 26: 415 (Abstract)

16. Slama G, Klein JC, Delage A, Ardila E, Lemaignen H, Papoz L, Tchobroutsky $G$ (1981) Correlation between the nature and the amount of carbohydrate in meal intake and insulin delivery by the artificial pancreas in 24 insulin-dependent diabetics. Diabetes 30: 101-105

17. Pehling G, Tessari P, Gerich JE, Haymond MW, Service FJ, Rizza RA (1984) Abnormal meal carbohydrate disposition in insulindependent diabetes. Relative Contribution of endogenous glucose production and initial splanchnic uptake and effect of intensive insulin therapy. J Clin Invest 74: 985-991

18. Deutsche Gesellschaft für Ernährung (1980) Ernährungsbericht 1980. Deutsche Gesellschaft für Ernährung, Frankfurt, FRG

19. Sheiham A (1983) Sugars and dental decay. Lancet 1: 282-284

20. National Advisory Committee on Nutrition Education (1983) Proposals for nutritional guidelines for health education in Britain. Lancet 2: 782-785

21. Schade DS, Santiago JV, Skyler JS, Rizza RA (1983) Intensive insulin therapy. Medical Exam Publ, Excerpta Medica, Princeton, NJ, USA

Received: 20 December 1984

and in revised form: 22 February 1985

Dr. Ernst A.Chantelau

Department of Medicine

Düsseldorf University

Moorenstraße 5

D-4 Düsseldorf 1

FRG 